\title{
Dietary supplementation of ginger (Zingiber officinale) essential oil exhibits positive immunomodulatory effects on the Neotropical catfish Pseudoplatystoma reticulatum without negative effects on fish liver histomorphometry
}

\author{
Rômullo Guilherme dos Santos Almeida ${ }^{1}\left(\mathbb{D}\right.$, Mateus Aranha Martins ${ }^{2,3}\left(\mathbb{D}\right.$, Fulvia Cristina Oliveira ${ }^{1}$ \\ ${\text { Fayane Espirito } \text { Santo }^{4}(\mathbb{D} \text {, Gleice Souza Calves }}^{4}\left(\mathbb{D}\right.$, Fabiana Pilarski ${ }^{5} \mathbb{D}$, Edsandra Campos Chagas ${ }^{6}$ \\ Carlos Eurico Fernandes $^{1}(\mathbb{D})$, Maurício Laterça Martins $^{2}(\mathbb{D})$ \& Cristiane Meldau de Campos ${ }^{1,4,7}(\mathbb{D})$ \\ ${ }^{1}$ Postgraduate Program in Animal Science, Federal University of Mato Grosso do Sul (UFMS) \\ Campo Grande, MS, Brazil \\ ${ }^{2}$ AQUOS - Aquatic Organisms Health Laboratory, Aquaculture Department \\ Federal University of Santa Catarina (UFSC), Florianópolis, SC, Brazil \\ ${ }^{3}$ Marine Shrimp Laboratory (LCM), Aquaculture Department, Federal University of Santa Catarina (UFSC) \\ Florianópolis, SC, Brazil \\ ${ }^{4}$ State University of Mato Grosso do Sul (UEMS), Zona Rural, Aquidauana, MS, Brazil \\ ${ }^{5}$ Aquaculture Center, São Paulo State University (CAUNESP), Jaboticabal, SP, Brazil \\ ${ }^{6}$ EMBRAPA Western Amazon, Manaus, AM, Brazil \\ ${ }^{7}$ Postgraduate Program in Zootechny, State University of Mato Grosso do Sul (UEMS) \\ Aquidauana, MS, Brazil \\ Corresponding author: Maurício Laterça Martins (mauricio.martins@ufsc.br)
}

\begin{abstract}
This study evaluated the dietary supplementation of ginger Zingiber officinale essential oil for the Neotropical catfish Pseudoplatystoma reticulatum, its effects on fish hematology, immunology, the response of these variables to induction of stress (exposition to air for $3 \mathrm{~min}$ ), and a bacterial challenge with Aeromonas hydrophila, and the effects on liver histomorphometry. Three levels of the ginger essential oil were evaluated $(0.5,1.0$ and $1.5 \%)$ in addition to a control group $(0 \%)$ in a feeding trial for 65 days in triplicate. Fish hematology and immunology were assessed at five different moments: after the feeding trial (0), after the stress induction (stress), and three points after the bacterial challenge (3, 6 and $24 \mathrm{~h}$ post-challenge). Fish fed the ginger essential oil supplemented diets did not exhibit significant differences between the hematocrit at the 0 -sample point and the $24 \mathrm{~h}$ post-challenge point $(P \geq 0.05)$, while fish fed the control diet presented significantly lower values for the hematocrit when comparing those same two moments $(P<0.05)$. The thrombocytes count for fish fed the $0.5 \%$ essential oil supplemented diet was significantly higher than all other groups after the feeding trial $(P<$ $0.05)$, and their total leukocytes count after the stress induction was also significantly higher than the other treatments $(P<0.05)$. Although the results mentioned above indicate that the ginger essential oil had positive health effects on the fish, no significant differences in survival after the challenge with $A$. hydrophila were observed $(P \geq 0.05)$. Lastly, histomorphometry suggests that the essential oil did not negatively impact fish hepatocytes.
\end{abstract}

Keywords: Pseudoplatystoma reticulatum; feed additive; hematology; immunology; aeromoniasis; bacterial challenge; hepatocyte

\section{INTRODUCTION}

The Neotropical catfish Pseudoplatystoma reticulatum, popularly known as cachara or surubim, exhibits great aquaculture potential due to its good growth performance, acceptance of industrialized feeds after conditioning, and the possibility of being reared in intensive production systems. In addition, it possesses desirable 
characteristics to consumers, such as low-fat content, flavourful flesh, and the lack of intramuscular bones (Crepaldi et al. 2006).

The emergence of diseases in aquaculture can be understood to be a disturbance in the balance between host, pathogen, and environment. For instance, poor water quality can lead to immunosuppressed fish and consequent infections by opportunistic pathogens, which, had good management practices been adopted, would be unlikely to cause harm to the animals. However, this preventive approach is not always successful, and other control measures may need to be employed, such as antibiotics. Still, the indiscriminate use of the latter can result in the selection of resistant pathogens, rendering these substances ineffective in disease outbreaks. There are also concerns regarding their accumulation in the animal's flesh and the subsequent safety to consumers (Defoirdt et al. 2011, Harikrishnan et al. 2011).

Due to the problems above, there has been a growing interest in the aquaculture industry for alternative disease management strategies, such as dietary inclusion of plant extracts to strengthen the health status of fish and their resistance to pathogens (Bulfon et al. 2015). Among these, essential oils complex natural mixtures of volatile organic compounds extracted through hydro distillation from plants (Bakkali et al. 2008)- have exhibited promising results for species such as channel catfish Ictalurus punctatus (Zheng et al. 2009), Nile tilapia Oreochromis niloticus (Brum et al. 2017) and sharpsnout seabream Diplodus puntazzo (Karagouni et al. 2005).

The essential oil of ginger Zingiber officinale -a plant that has been traditionally used for medicinal purposes (Rodrigues 2006)- has proven to be effective in enhancing the health status of fish submitted to bacterial challenges when provided in their diets (Brum et al. 2017, 2018a,b). Other studies also demonstrated in vitro antibacterial activity against fish pathogens (Shehata et al. 2013, Snuossi et al. 2016). However, to the best of our knowledge, it has not been evaluated as a feed additive for catfish $P$. reticulatum. Moreover, the liver is considered a good indicator of nutritional pathology, in which the deleterious or beneficial effects of specific feeds or feed additives on fish can be assessed through approaches such as hepatocyte morphometry (Rašković et al. 2011, Picoli et al. 2019).

Therefore, this study aimed to assess the hematology, immunology, and liver histomorphometry of $P$. reticulatum juveniles fed diets containing different ginger essential oils and the subsequent response to stress induction and a bacterial challenge with Aeromonas hydrophila.

\section{MATERIALS AND METHODS}

\section{Experimental design}

Three levels of ginger essential oil were included in a commercial feed ( $40 \%$ crude protein, $4 \mathrm{~mm}$ ): $0.5,1.0$ and $1.5 \%$, in addition to control $(0.0 \%)$, with three replicates per treatment in a completely randomized design. The inclusion of the essential oil consisted in incorporating a solution of the essential oil and $100 \mathrm{~g}$ of grain alcohol per feed $\mathrm{kg}$ through aspersion, according to Dairiki et al. (2013) and Brum et al. (2017). For the control group $(0.0 \%)$, the feed was sprinkled with grain alcohol only. After the procedure, the feeds were dried at $25^{\circ} \mathrm{C}$ for $24 \mathrm{~h}$ and subsequently stored under refrigeration until use.

The essential oil was extracted through hydrodistillation with a Clevenger apparatus from the rhizomes of ginger. The chemical composition (Fig. 1) was determined through gas chromatography-mass spectrometry (GC-MS) at the Laboratory of Medicinal Plants and Phytochemistry of the Embrapa Western Amazon, AM, Brazil according to Potzernheim et al. (2012).

One-hundred and eight Pseudoplatystoma reticulatum juveniles $(40.23 \pm 20.99 \mathrm{~g})$ were stocked in tanks of $80 \mathrm{~L}$ of useful volume under a density of $2.2 \mathrm{~kg} \mathrm{~m}^{-3}$. The 12 experimental units were located in an environment of low luminosity and possessed constant water exchange at $100 \%$ of the tank volume per day and aeration. Every two days, organic residues in the bottom of the units were also removed through siphoning. Dissolved oxygen, temperature, and $\mathrm{pH}$ were measured daily with a multi-parameter Hanna. Total ammonia was measured fortnightly with a commercial test (Labcon Test Amônia Tóxica Água Doce, Alcon ${ }^{\circledR}$, Camboriú, SC, Brazil). The mean values during the 65-day experiment were: temperature (21.59 $\left.\pm 2.68^{\circ} \mathrm{C}\right)$, dissolved oxygen $\left(7.95 \pm 1.08 \mathrm{mg} \mathrm{L}^{-1}\right)$, $\mathrm{pH}$ $(7.37 \pm 0.44)$, and total ammonia $\left(0.09 \pm 0.12 \mathrm{mg} \mathrm{L}^{-1}\right)$, values considered adequate for the culture of the species (Campos 2013).

The fish were fed two times a day (8:00 and 16:00 h) at the rate of $5 \%$ of their biomass, following the feed manufacturer's recommendation. At the end of the experiment, the animals were submitted to $24 \mathrm{~h}$ fasting before sampling for the blood collection. This work was approved by the Ethics Committee on the Use of Animals for experimentation (CEUA/UEMS - protocol 003/2018)

\section{Sampling and bacterial challenge}

Initially, two fish per tank were sampled after the feeding experiment to constitute the sample point "0". Then, the remaining animals were submitted to a stress 


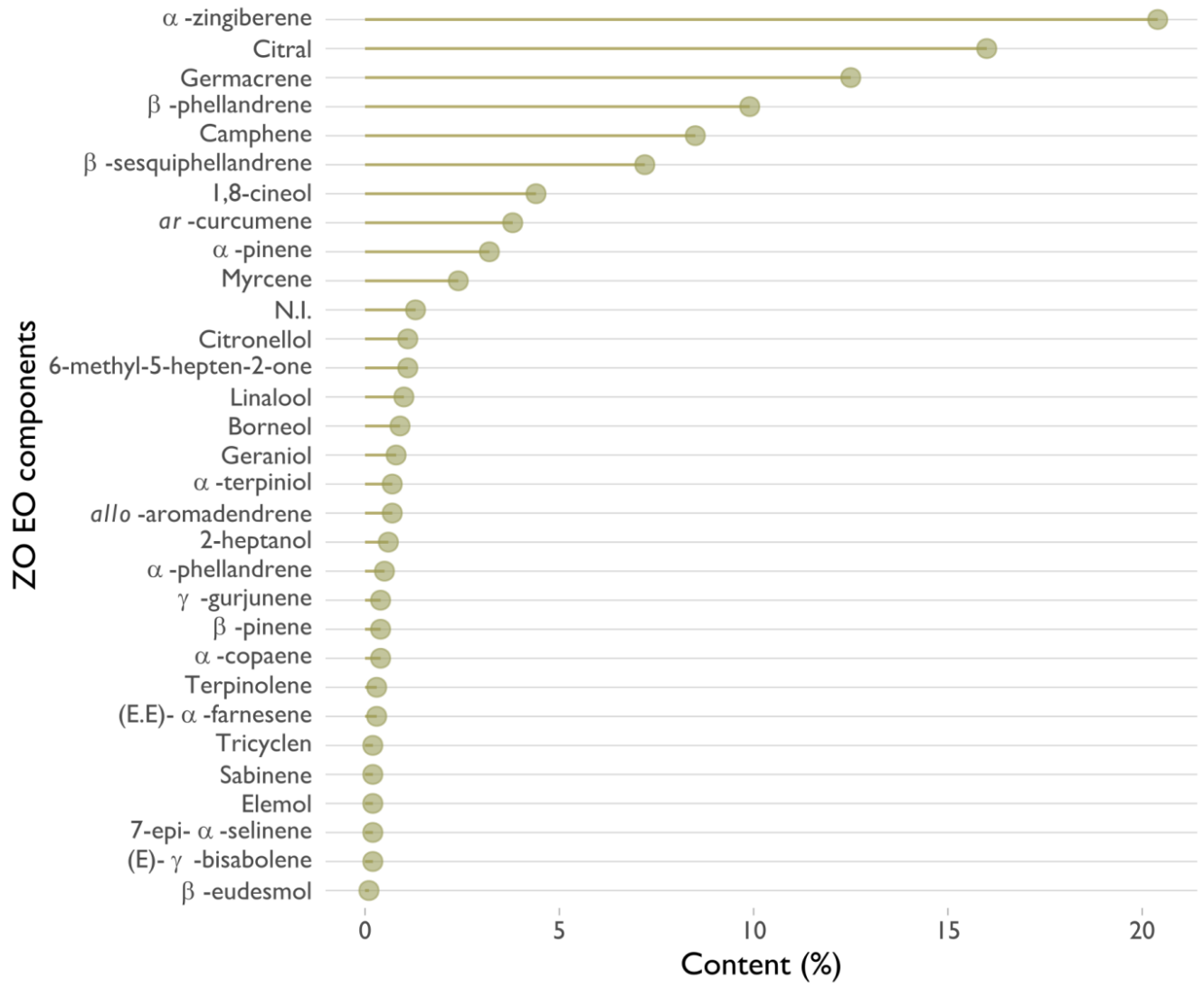

Figure 1. Composition of ginger Zingiber officinale essential oil (ZO EO) as determined by gas chromatography-mass spectrometry (GC-MS), adapted from Silva et al. (2020), a previous work performed by the same research group in which the same essential oil was used.

induction (capture and exposition to air for three minutes). Thirty minutes later, two additional fish per tank were sampled to constitute the sample point "stress," following Fagundes \& Urbinati's (2008) methodology.

The fish were challenged with an intraperitoneal injection of Aeromonas hydrophila. The A. hydrophila (KJ561021) strain colony was supplied by the Laboratory of Microbiology and Parasitology of Aquatic Organisms (LAPOA/CAUNESP) isolated from Pseudoplatystoma sp. exhibiting clinical signs. It was inoculated in Erlenmeyer flasks with trypticase soy agar (TSA) (Shotts \& Rimler 1973). Then, the medium was diluted in phosphate-buffered saline (PBS) and homogenized to determine the desired concentration of bacteria $\left(0.34 \times 10^{6} \mathrm{CFU}\right.$, established previously through an LD50 test) using $1 \mathrm{~mL}$ samples and a spectrophotometer (Femto-Cirrus 80). After this, the samples were centrifuged, the supernatant removed, and the volume was filled with PBS. Finally, the solution was transferred to sterile syringes.
After the challenge, six fish per treatment were sampled at three additional points: 3,6 and 24 h postchallenge. In all cases, blood $(1 \mathrm{~mL})$ was collected through puncture of the caudal vessel using syringes and needles bathed in EDTA (3\%) after the animals were anesthetized with clove oil $\left(50 \mathrm{mg} \mathrm{L}^{-1}\right)$.

Two days after the bacterial challenge, the fish exhibited erratic swimming. Dead fish presented clinical signs of aeromoniasis (Fig. 2), such as depigmentation of the epidermis, ascites, petechiae in the ventral region of the head, and pus secretion in the anus.

\section{Hematology and blood glucose}

The hematological variables analyzed were: hematocrit percentage $(\mathrm{Ht})$, through the microhematocrit method (Goldenfarb et al. 1971); hemoglobin (Hb), determined by the cyanmethemoglobin method (Collier 1944); and total count of red blood cells (RBC) in a Neubauer chamber using a dilution of 1:200 in a solution of sodium citrate and formalin $37-40 \%$ under an optical microscope. Based on the resulting values, the hemati- 


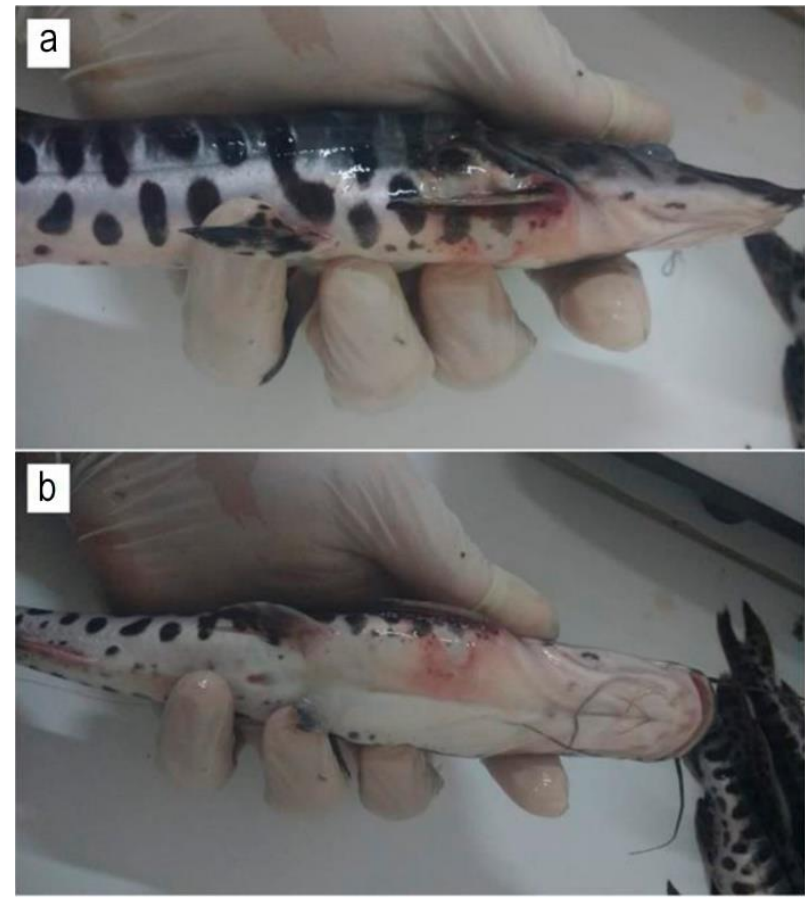

Figure 2. Catfish Pseudoplatystoma reticulatum exhibited clinical signs after intraperitoneal challenge with Aeromonas hydrophila, which was performed after a 65-day feeding assay evaluating dietary ginger (Zingiber officinale) oil. a) Hemorrhage at the base of the pectoral fin, b) hemorrhage at the ventral region of the body.

metry calculations were performed according to RanzaniPaiva et al. (2013): mean corpuscular volume (MCV) (fL) $=($ hematocrit $\times 10) /\left(\mathrm{n}^{\mathrm{o}}\right.$ erythrocytes $)$; mean corpuscular hemoglobin $(\mathrm{MCH})(\mathrm{pg})=($ hemoglobin $\times 10) /\left(\mathrm{n}^{\circ}\right.$ erythrocytes); mean corpuscular hemoglobin concentration $(\mathrm{MCHC})\left(\mathrm{g} \mathrm{dL}^{-1}\right)=($ hemoglobin $\times 100) /$ (hematocrit). Plasma glucose levels were measured using a glucometer Accu-Chek ${ }^{\circledR}$ Advantage (Roche Diagnóstica, Brazil), expressed in $\mathrm{mg} \mathrm{dL}^{-1}$.

\section{Immunology}

For the total count of leukocytes (white blood cells, WBC), thrombocytes, and the differential count of leukocytes, duplicates of blood extensions for each animal were made, air-dried, and stained with MayGrunwald-Giemsa-Wright according to Tavares-Dias \& Moraes (2004).

The analysis of the leukocyte respiratory burst activity was determined through a colorimetric assay based on the reduction of nitrobluetetrazolium (NBT) that results in precipitates, according to Anderson \& Siwicki (1995). Fifty microliter of heparinized blood were added to $50 \mu \mathrm{L}$ of NBT to determine the amount of precipitate. This mixture was homogenized and incubated. Poste-riorly, $50 \mu \mathrm{L}$ of it was diluted in $1 \mathrm{~mL}$ of dimethyl-formamide (DMF) and centrifuged before measuring the optical density (OD) of the solution at $540 \mathrm{~nm}$ (Sahoo et al. 2005).

\section{Liver histomorphometry}

At the end of the feeding experiment, three fish per treatment were euthanized by medullary collapse through anesthesia with clove oil for dissection and collection of the livers. The liver fragments were fixed

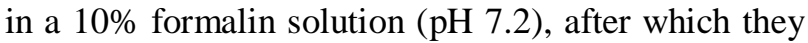
were dehydrated in a growing series of ethyl alcohol concentrations, clarified in xylol, embedded in paraffin, and cut at a thickness of $3 \mu \mathrm{m}$. Then, staining was performed with hematoxylin and eosin (Carson \& Hladik 2009), in which the slides remained in contact with the substances for $90 \mathrm{~s}$.

Twelve photos per sample were taken for histomorphometric analysis. The pictures of the histological liver sections (Fig. 3) were randomly taken with the help of a Nikon D5600 digital camera coupled to a Zeiss $^{\circledR}$ - Primo Star microscope. The morphometric analyses were performed with a MoticImage Plus 2.0 $\left(\right.$ Motic $^{\circledR}$ ) software.

The measurements were performed under a magnification of 100x. Six randomly selected hepatocytes from each photo were chosen for the measurement of hepatocyte area $\left(\mu \mathrm{m}^{2}\right)$ and perimeter $(\mu \mathrm{m})$; nucleus area $\left(\mu \mathrm{m}^{2}\right)$, perimeter $(\mu \mathrm{m})$, and diameter $(\mu \mathrm{m})$. Based on these measurements, the indirect morphometric variables were determined: nucleus/hepatocyte area relationship $(\mathrm{N} / \mathrm{C}($ area $)=$ nucleus area/hepatocyte area $\times 100$ ); nucleus/hepatocyte perimeter relationship (N/C (perimeter $)=$ nucleus perimeter $/$ hepatocyte perimeter $\times 100)$; volume of the hepatocyte nucleus $\left(\mathrm{Vn}\left(\mu \mathrm{m}^{3}\right)=\right.$ $\left.4 / 3 \times \pi \times r^{3}\right)$, where $r$ is the nucleus radius; and the hepatocyte nucleus circularity $(\mathrm{Cn}=4 \pi$ (nucleus area) / nucleus perimeter ${ }^{2}$ ) (Rodrigues et al. 2017).

\section{Statistical analysis}

Hematological and immunological data were analyzed with a two-way type II ANOVA (sample point $\times$ ginger essential oil concentration). Tukey's test was employed to compare the means by statistical significance for the main effects or the interaction effects (Zar 2010). Differences in the survival after the bacterial challenge were assessed with the Kaplan-Meier method. Histomorphometric data were analyzed with a one-way ANOVA, with Tukey's test being employed following statistical significance (Zar 2010).

In all cases, results were considered statistically significant if $P<0.05$. Data presented as mean \pm standard error of the mean. Statistical analysis and data visualizations were performed with $\mathrm{R}$ ( $\mathrm{R}$ Core Team 


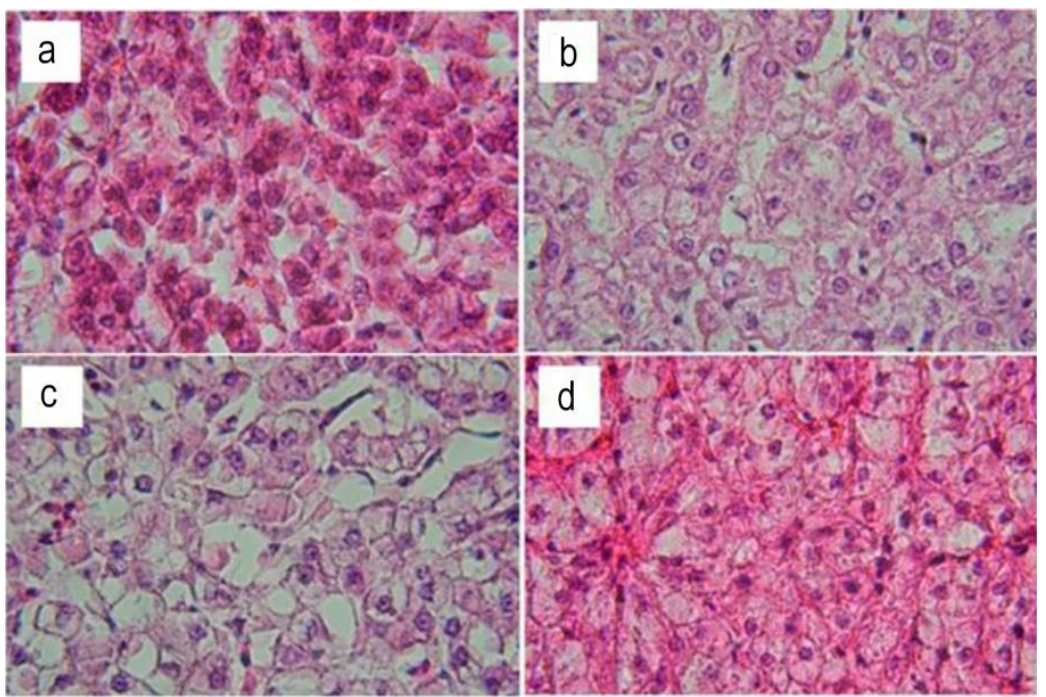

Figure 3. Pictures of the histological liver sections of the catfish Pseudoplatystoma reticulatum fed different concentrations. a) Control, b) $0.5 \%, \mathrm{c}) 1.0 \%$, d) $1.5 \%$ of ginger (Zingiber officinale) essential oil for 65 days.

2019). The main packages employed were car (Fox \& Weisberg 2019), lsmeans (Lenth 2016), and survival (Therneau 2020).

\section{RESULTS}

\section{Hematology and glucose}

Regarding the hematological variables, a significant interaction effect of ginger essential oil concentration $x$ sample point was observed only for hematocrit and $\mathrm{MCH}$ (Table 1). For the former, only fish fed the control diet exhibited a significantly lower value when comparing the initial sample point and the $24 \mathrm{~h}$ postchallenge sample point (Table 2). Conversely, the $\mathrm{MCH}$ for the fish fed the control diet exhibited a significantly higher value in the $24 \mathrm{~h}$ point, which was also significantly higher when compared with the other treatments in the same $24 \mathrm{~h}$ sample point (Table 2).

Significant effects for both factors were observed for RBC and glucose (Table 1). A significantly higher concentration of RBC when considering each treatment as a mean was found for the fish fed the $1.5 \%$ essential oil inclusion level (Table 2). When considering each sample point as a mean, significantly lower values were found for the three post-challenge sample points (Table 2 ). There was a statistically significant increase in blood glucose in the stress sample point compared to the initial sampling (Table 2). The higher values were maintained for the $3 \mathrm{~h}$ post-challenge point before decreasing significantly for the last sampling point.

Regarding $\mathrm{MCV}$ and $\mathrm{MCHC}$, there was a significant effect of the sample point only (Table 1). In both cases, the significantly lowest value was observed for the 24 $\mathrm{h}$ post-challenge sample point. Lastly, there was no significant effect in the case of hemoglobin (Table 1).

\section{Immunology}

A significant effect for the interaction between the two factors was found for WBC, thrombocytes, lymphocytes, and basophils (Table 3 ). In the case of WBC and lymphocytes, a pattern of significantly lower values in the sample points post-challenge for all treatments was observed (Table 4). There was also a significantly higher thrombocyte count for the fish of the $0.5 \%$ essential oil inclusion level in the 0 sample point (Table 4).

There was a significant effect of sample point only for immature leukocytes, monocytes, eosinophils, PAS+ (periodic acid-Shiff stained leukocyte), neutrophils, and respiratory burst activity (Table 3). Except for the respiratory burst activity, significantly lower values when considering means for each sample point were found for the post-challenge samples (Table 4).

\section{Liver histomorphometry}

A significant effect of ginger essential oil supplementation on hepatocyte morphometry was found for all variables evaluated (Table 5). Worthy of specific mention was that measurements of nucleus size (i.e. nucleus area, perimeter, and volume) were either statistically equal or higher in fish fed the essential oil supplemented diets compared to the control group. Regarding measures of hepatocyte size (i.e. hepatocyte area and perimeter), significantly higher values were found for fish fed the $1.5 \%$ essential oil supplemented diet compared to the other groups. 
Table 1. $P$-values for a two-way type II ANOVA show the effects of four ginger essential oil supplementation levels and five sampling points (after feeding trial, after stress induction, and 3,6 and $24 \mathrm{~h}$ after challenge with Aeromonas hydrophila) on hematological variables of Pseudoplatystoma reticulatum. *Statistically significant (5\%), RBC: red blood cells, MCV: mean corpuscular volume, MCH: mean corpuscular hemoglobin, MCHC: mean corpuscular hemoglobin concentration.

\begin{tabular}{llcc}
\hline \multirow{2}{*}{ Variable } & \multicolumn{3}{c}{ Two-way ANOVA $P$-values } \\
\cline { 2 - 4 } & Ginger & Sample point & Interaction \\
\hline RBC & $0.004^{*}$ & $<0.001^{*}$ & 0.683 \\
Hematocrit & 0.261 & $<0.001$ & $0.006^{*}$ \\
Hemoglobin & 0.981 & 0.368 & 0.471 \\
MCV & 0.132 & $<0.001^{*}$ & 0.264 \\
MCH & 0.051 & $<0.001$ & $0.014^{*}$ \\
MCHC & 0.624 & $<0.001^{*}$ & 0.076 \\
Glucose & $0.018^{*}$ & $<0.001^{*}$ & 0.588 \\
\hline
\end{tabular}

Table 2. Hematological variables and blood glucose of Pseudoplatystoma reticulatum fed different dietary levels of ginger Zingiber officinale essential oil (ZO EO) and submitted to stress induction and bacterial challenge with Aeromonas hydrophila. Data presented as mean \pm standard error of the mean. Different superscript numbers across ginger essential oil levels indicate significant differences when considering each treatment as a mean. Different superscript capital letters across sample points indicate significant differences when considering each sample point as a mean. For variables that a significant interaction effect was found, lowercase letters across columns and capital letters across rows indicate significant differences between means. In all instances, Tukey's test at a significance level of 0.05 was employed. Values are presented as mean \pm standard error of the mean. RBC: red blood cells, MCV: mean corpuscular volume, $\mathrm{MCH}$ : mean corpuscular hemoglobin, MCHC: mean corpuscular hemoglobin concentration.

\begin{tabular}{|c|c|c|c|c|c|c|}
\hline \multirow{2}{*}{ Variable } & \multirow{2}{*}{$\begin{array}{c}\text { ZO EO } \\
\text { level (\%) }\end{array}$} & \multicolumn{5}{|c|}{ Sample point } \\
\hline & & 0 & Stress & 3 & 6 & 24 \\
\hline \multirow[t]{4}{*}{$\operatorname{RBC}\left(\times 10^{6} \mu \mathrm{L}^{-1}\right)$} & 0 & $3.6 \pm 0.2^{\mathrm{A}, 1}$ & $3.4 \pm 0.4^{\mathrm{A}, 1}$ & $2.6 \pm 0.2^{\mathrm{B}, 1}$ & $2.9 \pm 1.1^{\mathrm{B}, 1}$ & $0.5 \pm 0.1^{\mathrm{B}, 1}$ \\
\hline & 0.5 & $3.5 \pm 0.3^{\mathrm{A}, 12}$ & $3.8 \pm 0.6^{\mathrm{A}, 12}$ & $2.5 \pm 0.2^{\mathrm{B}, 12}$ & $2.5 \pm 0.1^{\mathrm{B}, 12}$ & $1.9 \pm 0.7^{\mathrm{B}, 12}$ \\
\hline & 1 & $3.8 \pm 0.3^{\mathrm{A}, 1}$ & $3.5 \pm 0.3^{\mathrm{A}, 1}$ & $2.6 \pm 0.1^{\mathrm{B}, 1}$ & $2.1 \pm 0.1^{\mathrm{B}, 1}$ & $1.5 \pm 0.8^{\mathrm{B}, 1}$ \\
\hline & 1.5 & $5.1 \pm 0.7^{\mathrm{A}, 2}$ & $4.1 \pm 0.5^{\mathrm{A}, 2}$ & $2.9 \pm 0.2^{\mathrm{B}, 2}$ & $3.4 \pm 0.6^{\mathrm{B}, 2}$ & $2.6 \pm 0.8^{\mathrm{B}, 2}$ \\
\hline \multirow[t]{4}{*}{ Hematocrit (\%) } & 0 & $71.2 \pm 2.9^{\mathrm{a}}$ & $58.4 \pm 5.6^{\mathrm{ab}}$ & $77.8 \pm 1.6^{\mathrm{a}}$ & $42.7 \pm 1.8^{\mathrm{bc}}$ & $16.5 \pm 3.5^{\mathrm{c}}$ \\
\hline & 0.5 & $58.8 \pm 4.0^{\mathrm{ac}}$ & $62.2 \pm 1.4^{\mathrm{a}}$ & $58.8 \pm 4.8^{\mathrm{ac}}$ & $33.5 \pm 5.1^{\mathrm{b}}$ & $31.0 \pm 9.0^{\mathrm{bc}}$ \\
\hline & 1 & $68.0 \pm 5.2^{\mathrm{a}}$ & $51.0 \pm 2.3^{\mathrm{ab}}$ & $62.0 \pm 6.1^{\mathrm{ab}}$ & $38.0 \pm 6.0^{b}$ & $43.3 \pm 3.7^{\mathrm{ab}}$ \\
\hline & 1.5 & $59.3 \pm 3.7^{\mathrm{ab}}$ & $50.2 \pm 5.5^{\mathrm{ab}}$ & $68.8 \pm 6.3^{\mathrm{a}}$ & $42.6 \pm 1.9^{b}$ & $35.5 \pm 2.5^{\mathrm{b}}$ \\
\hline \multirow[t]{4}{*}{ Hemoglobin $\left(\mathrm{g} \mathrm{dL}^{-1}\right)$} & 0 & $11.8 \pm 2.7$ & $13.9 \pm 2.4$ & $13.4 \pm 3.8$ & $10.8 \pm 2.3$ & $9.3 \pm 4.6$ \\
\hline & 0.5 & $9.3 \pm 1.5$ & $16.4 \pm 2.5$ & $10.9 \pm 2.1$ & $7.4 \pm 1.1$ & $16.1 \pm 5.0$ \\
\hline & 1 & $10.9 \pm 2.2$ & $11.8 \pm 1.3$ & $15.3 \pm 3.9$ & $10.7 \pm 4.0$ & $9.5 \pm 2.3$ \\
\hline & 1.5 & $8.9 \pm 2.3$ & $9.8 \pm 1.1$ & $15.1 \pm 4.6$ & $16.1 \pm 3.3$ & $9.8 \pm 5.1$ \\
\hline \multirow[t]{4}{*}{ MCV (fL) } & 0 & $201.8 \pm 9.8^{\mathrm{AB}}$ & $170.2 \pm 22.0^{\mathrm{A}}$ & $273.0 \pm 16.0^{\mathrm{BC}}$ & $247.5 \pm 138.8^{\mathrm{AB}}$ & $419.6 \pm 225.6^{\mathrm{C}}$ \\
\hline & 0.5 & $157.2 \pm 24.1^{\mathrm{AB}}$ & $178.6 \pm 21.5^{\mathrm{A}}$ & $246.9 \pm 13.9^{\mathrm{BC}}$ & $119.2 \pm 18.2^{\mathrm{AB}}$ & $202.0 \pm 118.0^{\mathrm{C}}$ \\
\hline & 1 & $176.4 \pm 16.9^{\mathrm{AB}}$ & $150.5 \pm 11.0^{\mathrm{A}}$ & $251.2 \pm 20.3^{\mathrm{BC}}$ & $156.3 \pm 16.2^{\mathrm{AB}}$ & $482.1 \pm 223.3^{\mathrm{C}}$ \\
\hline & 1.5 & $133.3 \pm 8.3^{\mathrm{AB}}$ & $137.4 \pm 24.0^{\mathrm{A}}$ & $266.6 \pm 23.2^{\mathrm{BC}}$ & $130.9 \pm 26.6^{\mathrm{AB}}$ & $146.3 \pm 37.1^{\mathrm{C}}$ \\
\hline \multirow[t]{4}{*}{$\mathrm{MCH}(\mathrm{pg})$} & 0 & $32.3 \pm 6.8^{\mathrm{a}}$ & $39.1 \pm 4.1^{\mathrm{a}}$ & $49.0 \pm 11.1^{\mathrm{a}}$ & $64.8 \pm 37.6^{\mathrm{a}}$ & $162.5 \pm 55.8^{\mathrm{A}, \mathrm{b}}$ \\
\hline & 0.5 & $28.1 \pm 6.3$ & $44.5 \pm 6.9$ & $44.2 \pm 7.9$ & $22.9 \pm 1.1$ & $84.8 \pm 4.0^{\mathrm{AB}}$ \\
\hline & 1 & $27.5 \pm 4.0$ & $33.8 \pm 2.6$ & $58.8 \pm 15.4$ & $35.0 \pm 13.0$ & $80.7 \pm 19.5^{\mathrm{AB}}$ \\
\hline & 1.5 & $19.0 \pm 6.1$ & $27.0 \pm 4.6$ & $49.8 \pm 12.7$ & $48.4 \pm 8.6$ & $34.7 \pm 8.3^{\mathrm{B}}$ \\
\hline \multirow{4}{*}{$\mathrm{MCHC}\left(\mathrm{g} \mathrm{dL}^{-1}\right)$} & 0 & $13.8 \pm 2.4^{\mathrm{A}}$ & $26.2 \pm 4.6^{\mathrm{A}}$ & $21.5 \pm 5.8^{\mathrm{A}}$ & $25.9 \pm 6.4^{\mathrm{AB}}$ & $78.2 \pm 62.9^{\mathrm{B}}$ \\
\hline & 0.5 & $13.2 \pm 3.3^{\mathrm{A}}$ & $26.3 \pm 3.8^{\mathrm{A}}$ & $20.1 \pm 2.5^{\mathrm{A}}$ & $21.4 \pm 3.4^{\mathrm{AB}}$ & $62.0 \pm 34.2^{\mathrm{B}}$ \\
\hline & 1 & $16.7 \pm 3.6^{\mathrm{A}}$ & $22.9 \pm 2.0^{\mathrm{A}}$ & $27.3 \pm 9.0^{\mathrm{A}}$ & $25.9 \pm 6.2^{\mathrm{AB}}$ & $23.4 \pm 7.7^{\mathrm{B}}$ \\
\hline & 1.5 & $9.4 \pm 1.7^{\mathrm{A}}$ & $19.9 \pm 2.2^{\mathrm{A}}$ & $15.1 \pm 3.6^{\mathrm{A}}$ & $39.1 \pm 8.9^{\mathrm{AB}}$ & $26.9 \pm 12.5^{\mathrm{B}}$ \\
\hline \multirow[t]{4}{*}{ Glucose $\left(\mathrm{mg} \mathrm{dL}^{-1}\right)$} & 0 & $51.8 \pm 1.5^{\mathrm{A}}$ & $90.3 \pm 7.5^{\mathrm{B}}$ & $85.3 \pm 9.1^{\mathrm{B}}$ & $30.7 \pm 7.3^{\mathrm{AC}}$ & $9.0 \pm 0.0^{\mathrm{C}}$ \\
\hline & 0.5 & $40.7 \pm 3.6^{\mathrm{A}}$ & $74.7 \pm 10.1^{\mathrm{B}}$ & $56.0 \pm 8.9^{\mathrm{B}}$ & $34.8 \pm 8.4^{\mathrm{AC}}$ & $15.0 \pm 0.0^{\mathrm{C}}$ \\
\hline & 1 & $48.5 \pm 5.3^{\mathrm{A}}$ & $87.0 \pm 13.2^{\mathrm{B}}$ & $97.3 \pm 21.5^{\mathrm{B}}$ & $24.6 \pm 2.5^{\mathrm{AC}}$ & $10.0 \pm 0.0^{\mathrm{C}}$ \\
\hline & 1.5 & $64.8 \pm 6.2^{\mathrm{A}}$ & $104.8 \pm 6.6^{\mathrm{B}}$ & $83.7 \pm 11.2^{\mathrm{B}}$ & $42.6 \pm 9.1^{\mathrm{AC}}$ & $11.0 \pm 1.0^{\mathrm{C}}$ \\
\hline
\end{tabular}


Table 3. $P$-values for a two-way type II ANOVA show the effects of four ginger essential oil supplementation levels and five sampling points (after feeding trial, after stress induction, and 3, 6 and $24 \mathrm{~h}$ after challenge with Aeromonas hydrophila) on immunological variables of Pseudoplatystoma reticulatum. *Statistically significant (5\%), WBC: white blood cells, PAS $^{+}$: periodic acid-Shiff stained leukocyte.

\begin{tabular}{lccc}
\hline \multirow{2}{*}{ Variable } & \multicolumn{3}{c}{ Two-way ANOVA $P$-values } \\
\cline { 2 - 4 } & Ginger & Sample point & Ginger*Sample point \\
\hline WBC & 0.752 & $<0.001$ & $0.004^{*}$ \\
Thrombocytes & 0.010 & $<0.001$ & $0.006^{*}$ \\
Lymphocytes & 0.514 & $<0.001$ & $0.009^{*}$ \\
Immature leukocytes & 0.117 & $<0.001^{*}$ & 0.603 \\
Monocytes & 0.056 & $<0.001^{*}$ & 0.260 \\
Eosinophils & 0.443 & $<0.001^{*}$ & 0.647 \\
PAS $^{+}$ & 0.519 & $0.002^{*}$ & 0.730 \\
Neutrophils & 0.362 & $<0.001^{*}$ & 0.837 \\
Basophils & 0.097 & $<0.001$ & $0.035^{*}$ \\
Respiratory burst activity & 0.846 & $0.003^{*}$ & 0.538 \\
\hline
\end{tabular}

\section{Survival after bacterial challenge}

There was no significant difference between the survival curves after the fish were submitted to the bacterial challenge (Fig. 4).

\section{DISCUSSION}

Evaluating the hematological variables of reared fish is useful to monitor their physiological and health status because their values reflect the animal's response to factors such as nutrition, stress, and microbial infections (Fazio 2019). In this study, when considering each ginger essential oil supplementation level as a mean, we found that the fish fed the highest concentration $(1.5 \%)$ exhibited significantly higher values of RBC when compared to fish fed the control diet, suggesting enhanced blood oxygen-carrying capacity. Ferri-Lagneau et al. (2012) demonstrated that ginger extract stimulated hematopoiesis in zebrafish (Danio rerio), which could explain our results. Another possibility could be that the ginger essential oil -due to the antioxidant potential of its constituents (Jeena et al. 2013)- may have protected the RBC against hemolysis by free radicals (Mohammadi et al. 2020). When observing the hematocrit values, only fish fed the control diet exhibited a significantly lower value when comparing the initial sampling point (0) and the final post-challenge sampling point $(24 \mathrm{~h})$. Fish fed the ginger essential oil supplemented diets seem to have maintained more stable values, resulting in nonsignificant differences when comparing the initial sampling point ( 0 ) and the last post-challenge sampling point ( $24 \mathrm{~h}$ ), which could also have been a result of the ginger components properties.
In hemoglobin, no significant effect was observed, either considering each factor or their interaction, consistent with studies evaluating a ginger essential oil supplemented diet for Nile tilapia Oreochromis niloticus (Brum et al. 2017) and ginger supplemented diet for beluga (Huso huso) (Kanani et al. 2014), in which no effect of the supplemented diets on fish hemoglobin was found.

In addition to the significantly lower values of RBC for the three post-challenge points when compared with the pre-challenge results, the lowest values for $\mathrm{MCV}$ and $\mathrm{MCHC}$, when considering each sampling point as a mean, were found in the $24 \mathrm{~h}$ post-challenge point. These alterations in the fish hematology are to be expected for fish infected with diseases (Hrubec \& Smith 2010). Regarding the $\mathrm{MCH}$, the results are a reflection of what occurred, especially with the RBC. Although it was not a statistically significant result, there was a trend for erythrocyte values to increase as the ginger essential oil supplementation increased in the $24 \mathrm{~h}$ post-challenge sample point. As erythrocytes count is the denominator in that hematimetry calculation, that resulted in a significantly higher value of $\mathrm{MCH}$ when comparing the fish fed the control diet with the animals fed the $1.5 \%$ ginger essential oil supplemented diet at the $24 \mathrm{~h}$ post-challenge sample point.

Blood glucose can be used as an indicator of stress in fish, as it tends to increase due to the release of catecholamines and corticosteroids during stressful situations (Ross \& Ross 2008). This study found that its level increased significantly after the fish were submitted to the stress induction. It then reached the 
Table 4. Immunological variables of Pseudoplatystoma reticulatum fed different dietary levels of ginger Zingiber officinale essential oil (ZO-EO) and submitted to stress induction and bacterial challenge with Aeromonas hydrophila. Data presented as mean \pm standard error of the mean. Different superscript numbers across ginger essential oil levels indicate significant differences when considering each treatment as a mean. Different superscript capital letters across sample points indicate significant differences when considering each sample point as a mean. For variables that a significant interaction effect was found, lowercase letters across columns and capital letters across rows indicate significant differences between means. In all instances, Tukey's test at a significance level of 0.05 was employed. PAS $^{+}$: periodic acid-Shiff stained leukocyte, WBC: white blood cells, OD: optical density.

\begin{tabular}{|c|c|c|c|c|c|c|}
\hline \multirow{2}{*}{ Variable } & \multirow{2}{*}{$\begin{array}{c}\mathrm{ZO}-\mathrm{EO} \\
\text { level (\%) }\end{array}$} & \multicolumn{5}{|c|}{ Sample point } \\
\hline & & 0 & Stress & 3 & 6 & 24 \\
\hline \multirow{4}{*}{$\begin{array}{l}\text { WBC } \\
\left(\times 10^{3} \mu \mathrm{L}^{-1}\right)\end{array}$} & 0 & $129.6 \pm 6.7^{\mathrm{a}}$ & $138.4 \pm 14.5^{\mathrm{a}}$ & $25.7 \pm 2.6^{\mathrm{b}}$ & $16.7 \pm 0.0^{\mathrm{b}}$ & $0.6 \pm 0.2^{b}$ \\
\hline & 0.5 & $81.5 \pm 10.0^{\mathrm{a}}$ & $149.3 \pm 25.4^{b}$ & $30.8 \pm 2.8^{a c}$ & $56.5 \pm 4.2^{\mathrm{ac}}$ & $5.0 \pm 0.1^{c}$ \\
\hline & 1 & $107.1 \pm 10.0^{\mathrm{a}}$ & $117.3 \pm 9.0^{\mathrm{a}}$ & $71.4 \pm 5.7^{\mathrm{ab}}$ & $24.5 \pm 2.1^{\mathrm{bc}}$ & $3.2 \pm 1.4^{\mathrm{c}}$ \\
\hline & 1.5 & $118.7 \pm 17.4^{\mathrm{a}}$ & $112.0 \pm 13.6^{\mathrm{a}}$ & $37.6 \pm 5.5^{\mathrm{b}}$ & $35.4 \pm 7.2^{\mathrm{b}}$ & $5.6 \pm 0.5^{\mathrm{b}}$ \\
\hline \multirow{4}{*}{$\begin{array}{l}\text { Thrombocytes } \\
\left(\times 10^{3} \mu \mathrm{L}^{-1}\right)\end{array}$} & 0 & $81.1 \pm 25.1^{\mathrm{A}, \mathrm{ab}}$ & $100.9 \pm 14.2^{\mathrm{a}}$ & $69.0 \pm 3.6^{\mathrm{ab}}$ & $48.1 \pm 0.0^{\mathrm{ab}}$ & $8.8 \pm 4.5^{\mathrm{b}}$ \\
\hline & 0.5 & $163.1 \pm 16.0^{\mathrm{B}, \mathrm{a}}$ & $89.5 \pm 13.7^{\mathrm{ab}}$ & $57.4 \pm 13.1^{\mathrm{b}}$ & $41.9 \pm 4.8^{\mathrm{b}}$ & $34.4 \pm 24.5^{\mathrm{b}}$ \\
\hline & 1 & $62.1 \pm 5.2^{\mathrm{A}}$ & $63.2 \pm 4.6$ & $65.2 \pm 14.5$ & $36.9 \pm 5.6$ & $22.4 \pm 11.3$ \\
\hline & 1.5 & $72.9 \pm 9.7^{\mathrm{A}}$ & $105.5 \pm 24.7$ & $60.9 \pm 17.2$ & $68.2 \pm 26.1$ & $57.0 \pm 8.0$ \\
\hline \multirow{4}{*}{$\begin{array}{l}\text { Lymphocytes } \\
\left(\times 10^{3} \mu \mathrm{L}^{-1}\right)\end{array}$} & 0 & $95.9 \pm 10.6^{\mathrm{ab}}$ & $103.9 \pm 13.1^{\mathrm{a}}$ & $22.6 \pm 2.5^{b c}$ & $16.5 \pm 0.0^{\mathrm{bc}}$ & $0.5 \pm 0.1^{\mathrm{c}}$ \\
\hline & 0.5 & $49.2 \pm 4.2^{\mathrm{ab}}$ & $97.7 \pm 17.2^{\mathrm{a}}$ & $25.7 \pm 4.0^{\mathrm{b}}$ & $52.3 \pm 3.3^{\mathrm{ab}}$ & $4.9 \pm 0.1^{b}$ \\
\hline & 1 & $64.8 \pm 9.3^{\mathrm{ab}}$ & $81.8 \pm 7.5^{\mathrm{a}}$ & $58.1 \pm 5.2^{\mathrm{abc}}$ & $23.8 \pm 2.2^{b c}$ & $2.8 \pm 1.2^{\mathrm{c}}$ \\
\hline & 1.5 & $80.1 \pm 16.3^{\mathrm{ab}}$ & $81.6 \pm 11.8^{\mathrm{a}}$ & $32.6 \pm 4.4^{b c}$ & $34.4 \pm 7.0^{\mathrm{abc}}$ & $5.0 \pm 0.3^{c}$ \\
\hline \multirow{4}{*}{$\begin{array}{l}\text { Immature } \\
\text { leukocytes } \\
\left(\times 10^{3} \mu \mathrm{L}^{-1}\right)\end{array}$} & 0 & $5.8 \pm 1.3^{\mathrm{A}}$ & $1.6 \pm 0.5^{\mathrm{B}}$ & $0.5 \pm 0.1^{\mathrm{BC}}$ & $0.0 \pm 0.0^{\mathrm{BC}}$ & $0.0 \pm 0.0^{\mathrm{C}}$ \\
\hline & 0.5 & $5.4 \pm 1.9^{\mathrm{A}}$ & $5.4 \pm 1.8^{B}$ & $0.4 \pm 0.1^{\mathrm{BC}}$ & $1.8 \pm 1.0^{\mathrm{BC}}$ & $0.1 \pm 0.1^{\mathrm{C}}$ \\
\hline & 1 & $8.9 \pm 1.6^{\mathrm{A}}$ & $3.8 \pm 1.5^{\mathrm{B}}$ & $2.2 \pm 1.0^{\mathrm{BC}}$ & $0.0 \pm 0.0^{\mathrm{BC}}$ & $0.1 \pm 0.0^{\mathrm{C}}$ \\
\hline & 1.5 & $10.6 \pm 3.1^{\mathrm{A}}$ & $4.6 \pm 1.1^{\mathrm{B}}$ & $1.1 \pm 0.3^{\mathrm{BC}}$ & $0.1 \pm 0.1^{\mathrm{BC}}$ & $0.0 \pm 0.0^{\mathrm{C}}$ \\
\hline \multirow{4}{*}{$\begin{array}{l}\text { Monocytes } \\
\left(\times 10^{3} \mu \mathrm{L}^{-1}\right)\end{array}$} & 0 & $4.5 \pm 1.6^{\mathrm{A}}$ & $6.7 \pm 1.3^{\mathrm{A}}$ & $1.1 \pm 0.1^{\mathrm{B}}$ & $0.0 \pm 0.0^{\mathrm{B}}$ & $0.0 \pm 0.0^{\mathrm{B}}$ \\
\hline & 0.5 & $7.0 \pm 2.7^{\mathrm{A}}$ & $15.0 \pm 4.1^{\mathrm{A}}$ & $0.4 \pm 0.1^{\mathrm{B}}$ & $1.0 \pm 0.7^{\mathrm{B}}$ & $0.0 \pm 0.0^{\mathrm{B}}$ \\
\hline & 1 & $8.8 \pm 1.2^{\mathrm{A}}$ & $8.0 \pm 1.1^{\mathrm{A}}$ & $4.2 \pm 2.0^{\mathrm{B}}$ & $0.1 \pm 0.1^{\mathrm{B}}$ & $0.1 \pm 0.0^{\mathrm{B}}$ \\
\hline & 1.5 & $6.0 \pm 1.0^{\mathrm{A}}$ & $7.7 \pm 1.6^{\mathrm{A}}$ & $0.4 \pm 0.0^{\mathrm{B}}$ & $0.3 \pm 0.1^{\mathrm{B}}$ & $0.2 \pm 0.1^{\mathrm{B}}$ \\
\hline \multirow{4}{*}{$\begin{array}{l}\text { Eosinophils } \\
\left(\times 10^{3} \mu \mathrm{L}^{-1}\right)\end{array}$} & 0 & $2.6 \pm 1.0^{\mathrm{A}}$ & $2.9 \pm 0.5^{\mathrm{A}}$ & $0.3 \pm 0.1^{\mathrm{B}}$ & $0.1 \pm 0.0^{\mathrm{B}}$ & $0.0 \pm 0.0^{\mathrm{B}}$ \\
\hline & 0.5 & $0.8 \pm 0.4^{\mathrm{A}}$ & $2.8 \pm 1.1^{\mathrm{A}}$ & $0.3 \pm 0.1^{\mathrm{B}}$ & $0.2 \pm 0.2^{\mathrm{B}}$ & $0.0 \pm 0.0^{\mathrm{B}}$ \\
\hline & 1 & $2.4 \pm 1.2^{\mathrm{A}}$ & $1.6 \pm 0.4^{\mathrm{A}}$ & $1.2 \pm 0.3^{\mathrm{B}}$ & $0.1 \pm 0.0^{\mathrm{B}}$ & $0.0 \pm 0.0^{\mathrm{B}}$ \\
\hline & 1.5 & $1.2 \pm 0.6^{\mathrm{A}}$ & $2.2 \pm 0.7^{\mathrm{A}}$ & $0.4 \pm 0.1^{\mathrm{B}}$ & $0.2 \pm 0.0^{\mathrm{B}}$ & $0.1 \pm 0.0^{\mathrm{B}}$ \\
\hline \multirow{4}{*}{$\begin{array}{l}\mathrm{PAS}^{+} \\
\left(\times 10^{3} \mu \mathrm{L}^{-1}\right)\end{array}$} & 0 & $0.5 \pm 0.2^{\mathrm{AB}}$ & $1.0 \pm 0.2^{\mathrm{A}}$ & $0.0 \pm 0.0^{\mathrm{B}}$ & $0.0 \pm 0.0^{\mathrm{B}}$ & $0.0 \pm 0.0^{\mathrm{B}}$ \\
\hline & 0.5 & $0.5 \pm 0.2^{\mathrm{AB}}$ & $2.4 \pm 1.9^{\mathrm{A}}$ & $0.3 \pm 0.0^{\mathrm{B}}$ & $0.0 \pm 0.0^{\mathrm{B}}$ & $0.0 \pm 0.0^{\mathrm{B}}$ \\
\hline & 1 & $2.1 \pm 1.3^{\mathrm{AB}}$ & $1.0 \pm 0.3^{\mathrm{A}}$ & $0.4 \pm 0.1^{\mathrm{B}}$ & $0.0 \pm 0.0^{\mathrm{B}}$ & $0.0 \pm 0.0^{\mathrm{B}}$ \\
\hline & 1.5 & $0.8 \pm 0.3^{\mathrm{AB}}$ & $2.0 \pm 0.6^{\mathrm{A}}$ & $0.2 \pm 0.1^{\mathrm{B}}$ & $0.0 \pm 0.0^{\mathrm{B}}$ & $0.2 \pm 0.1^{\mathrm{B}}$ \\
\hline \multirow{4}{*}{$\begin{array}{l}\text { Neutrophils } \\
\left(\times 10^{3} \mu \mathrm{L}^{-1}\right)\end{array}$} & 0 & $14.5 \pm 3.3^{\mathrm{A}}$ & $10.0 \pm 2.7^{\mathrm{A}}$ & $0.7 \pm 0.1^{\mathrm{B}}$ & $0.1 \pm 0.0^{\mathrm{B}}$ & $0.0 \pm 0.0^{\mathrm{B}}$ \\
\hline & 0.5 & $15.7 \pm 4.0^{\mathrm{A}}$ & $21.2 \pm 7.0^{\mathrm{A}}$ & $2.4 \pm 1.6^{\mathrm{B}}$ & $0.6 \pm 0.3^{\mathrm{B}}$ & $0.0 \pm 0.0^{\mathrm{B}}$ \\
\hline & 1 & $13.8 \pm 2.8^{\mathrm{A}}$ & $13.2 \pm 4.7^{\mathrm{A}}$ & $4.3 \pm 1.6^{\mathrm{B}}$ & $0.2 \pm 0.1^{\mathrm{B}}$ & $0.1 \pm 0.1^{\mathrm{B}}$ \\
\hline & 1.5 & $15.2 \pm 3.5^{\mathrm{A}}$ & $9.4 \pm 1.4^{\mathrm{A}}$ & $2.3 \pm 0.8^{\mathrm{B}}$ & $0.3 \pm 0.2^{\mathrm{B}}$ & $0.1 \pm 0.1^{\mathrm{B}}$ \\
\hline \multirow{4}{*}{$\begin{array}{l}\text { Basophils } \\
\left(\times 10^{3} \mu \mathrm{L}^{-1}\right)\end{array}$} & 0 & $4.3 \pm 0.8^{\mathrm{a}}$ & $12.1 \pm 1.4^{\mathrm{A}, \mathrm{b}}$ & $0.5 \pm 0.1^{\mathrm{a}}$ & $0.0 \pm 0.0^{\mathrm{a}}$ & $0.0 \pm 0.0^{\mathrm{a}}$ \\
\hline & 0.5 & $3.0 \pm 1.2$ & $5.2 \pm 1.1^{\mathrm{B}}$ & $1.2 \pm 0.3$ & $0.7 \pm 0.4$ & $0.0 \pm 0.0$ \\
\hline & 1 & $6.4 \pm 1.7^{\mathrm{ab}}$ & $7.9 \pm 2.7^{\mathrm{AB}, \mathrm{a}}$ & $1.0 \pm 0.3^{b}$ & $0.2 \pm 0.0^{\mathrm{b}}$ & $0.1 \pm 0.0^{b}$ \\
\hline & 1.5 & $6.5 \pm 1.8$ & $4.5 \pm 1.3^{\text {В }}$ & $0.6 \pm 0.2$ & $0.1 \pm 0.1$ & $0.1 \pm 0.1$ \\
\hline \multirow{4}{*}{$\begin{array}{l}\text { Respiratory burst } \\
\text { activity (OD) }\end{array}$} & 0 & $0.15 \pm 0.02$ & $0.14 \pm 0.03$ & $0.22 \pm 0.02$ & $0.19 \pm 0.05$ & $0.15 \pm 0.02$ \\
\hline & 0.5 & $0.09 \pm 0.02$ & $0.16 \pm 0.03$ & $0.19 \pm 0.03$ & $0.16 \pm 0.03$ & $0.25 \pm 0.00$ \\
\hline & 1 & $0.14 \pm 0.03$ & $0.16 \pm 0.02$ & $0.18 \pm 0.01$ & $0.15 \pm 0.02$ & $0.22 \pm 0.04$ \\
\hline & 1.5 & $0.15 \pm 0.02$ & $0.17 \pm 0.02$ & $0.20 \pm 0.03$ & $0.15 \pm 0.01$ & $0.18 \pm 0.02$ \\
\hline
\end{tabular}

statistically lowest value in the $24 \mathrm{~h}$ post-challenge point, probably resulting from both the infection and fasting.

Feeding fish with diets supplemented with essential oils has been shown to produce immunomodulatory effects in various studies (Sutili et al. 2018). However, these effects are not consistent. For instance, Valladão et al. (2017) fed Nile tilapia with diets containing essential oils of Mentha piperita and Melaleuca alternifolia and sampled the fish on the $7^{\text {th }}, 30^{\text {th }}$, and $60^{\text {th }}$ days. Except for a significant effect on the count of monocytes at the 30-day sampling point, no alterations on total leukocyte count or the differential counts were observed. In our case, after the feeding trial, only a sig- 
Table 5. Liver histomorphometry of Pseudoplatystoma reticulatum fed different dietary levels of ginger Zingiber officinale essential oil (ZO-EO). Data presented as mean \pm standard error of the mean. Different letters on the same line indicate statistical difference by Tukey's test $(P<0.05)$. N/C: nucleus to hepatocyte ratio as regards area or perimeter.

\begin{tabular}{lccccc}
\hline \multirow{2}{*}{ Variable } & \multicolumn{5}{c}{ ZO-EO level $(\%)$} \\
\cline { 2 - 5 } & 0 & 0.5 & 1 & \multirow{2}{*}{-value } \\
\hline Nucleus circularity $(0-1)$ & $0.89 \pm 0.00^{\mathrm{a}}$ & $0.91 \pm 0.00^{\mathrm{b}}$ & $0.91 \pm 0.00^{\mathrm{b}}$ & $0.91 \pm 0.00^{\mathrm{b}}$ & $<0.001$ \\
Nucleus area $\left(\mu \mathrm{m}^{2}\right)$ & $12.58 \pm 0.18^{\mathrm{a}}$ & $13.71 \pm 0.18^{\mathrm{b}}$ & $15.57 \pm 0.22^{\mathrm{c}}$ & $13.77 \pm 0.20^{\mathrm{b}}$ & $<0.001$ \\
Hepatocyte area $\left(\mu \mathrm{m}^{2}\right)$ & $96.37 \pm 1.57^{\mathrm{ab}}$ & $92.83 \pm 1.13^{\mathrm{a}}$ & $100.5 \pm 1.38^{\mathrm{b}}$ & $109.9 \pm 1.19^{\mathrm{c}}$ & $<0.001$ \\
N/C (area) $(\%)$ & $13.53 \pm 0.23^{\mathrm{a}}$ & $15.12 \pm 0.24^{\mathrm{b}}$ & $15.85 \pm 0.24^{\mathrm{b}}$ & $12.72 \pm 0.18^{\mathrm{a}}$ & $<0.001$ \\
Nucleus perimeter $(\mu \mathrm{m})$ & $13.23 \pm 0.09^{\mathrm{a}}$ & $13.66 \pm 0.09^{\mathrm{b}}$ & $14.55 \pm 0.10^{\mathrm{c}}$ & $13.71 \pm 0.09^{\mathrm{b}}$ & $<0.001$ \\
Hepatocyte perimeter $(\mu \mathrm{m})$ & $36.73 \pm 0.29^{\mathrm{a}}$ & $36.32 \pm 0.24^{\mathrm{a}}$ & $37.76 \pm 0.26^{\mathrm{b}}$ & $39.65 \pm 0.22^{\mathrm{c}}$ & $<0.001$ \\
N/C (perimeter) $(\%)$ & $36.35 \pm 0.31^{\mathrm{a}}$ & $37.89 \pm 0.31^{\mathrm{b}}$ & $38.79 \pm 0.31^{\mathrm{b}}$ & $34.72 \pm 0.26^{\mathrm{c}}$ & $<0.001$ \\
Nucleus volume $\left(\mu \mathrm{m}^{3}\right)$ & $32.35 \pm 0.46^{\mathrm{a}}$ & $33.26 \pm 0.67^{\mathrm{a}}$ & $35.64 \pm 0.45^{\mathrm{b}}$ & $33.66 \pm 0.70^{\mathrm{ab}}$ & $<0.001$ \\
\hline
\end{tabular}

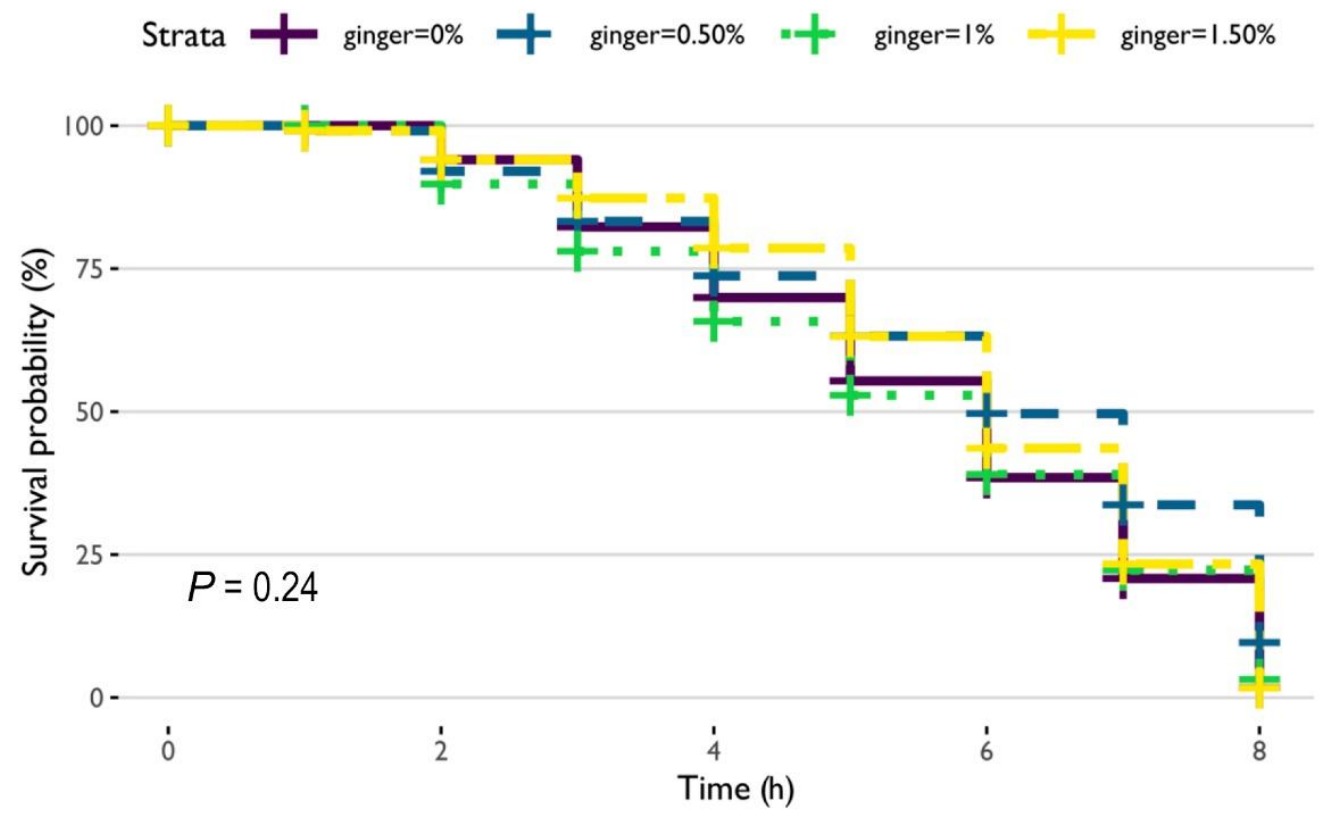

Figure 4. Kaplan-Meier cumulative survival curves for Pseudoplatystoma reticulatum catfish fed different dietary levels of ginger Zingiber officinale essential oil and challenged with Aeromonas hydrophila.

nificant difference between treatments in the thrombocyte count was found, in which a significantly higher value occurred in fish fed the $0.5 \%$ ginger essential oil supplemented diet. Thrombocytes are part of the fish's innate immune system, having phagocytosis and coagulation capacity (Biller-Takahashi \& Urbinati 2014). Also, regarding the $0.5 \%$ treatment, only fish fed this diet had a significantly higher WBC count after the induction of stress. Fish immune response to stress is complex, with studies reporting both immunosuppression and immunostimulation (Wendelaar-Bonga 1997), and it seems that the ginger supplementation modulated this response.

Interestingly, although it was not statistically significant, the numerically highest survival after the bacterial challenge occurred in fish fed the $0.5 \%$ supplemented diet. Perhaps the induction of stress impaired the immune response of the fish, reducing the positive effect obtained after the feeding trial and rendering effects on post-challenge survival less intense.

Overall, the values for the hemato-immunological variables obtained after the feeding assay are within the range of values for those reported for healthy Pseudoplatystoma reticulatum (Sanchez et al. 2014, Jerônimo et al. 2015, Mouriño et al. 2016, Sousa et al. 2019, Campos et al. 2020, Silva et al. 2020).

Fish undergoing various types of nutritional stressors, such as feed restriction (Souza et al. 2001), unbalanced diets (Rašković et al. 2019) and lower fee- 
ding frequency (Rodrigues et al. 2017), or exhibiting nutritional pathologies due to certain plant-derived feed additives (Zakęś et al. 2008), were found to exhibit smaller hepatocyte nuclei. Accordingly, the essential oil supplementation at the levels evaluated seem to not have been a stressor in our study, as the measures of hepatocyte nuclear size (i.e. nuclear area, nuclear perimeter, and nuclear volume) were not significantly lower than fish fed the control diet.

Although fish fed the 0.5 and $1.0 \%$ levels did not differ significantly from the control ones, the $1.5 \%$ group exhibited a significantly higher hepatocyte area when compared to the other ones, perhaps suggesting a better nutritional status. Increased fish hepatocyte size has been associated with increased reserves of glycogen and lipids, suggesting an enhanced liver nutritional status (Oliveira et al. 2010, Ferreira et al. 2016). This hypothesis could be evaluated in a specific study.

Feed additives may enhance the early stages of the immune response of fish. Judging on the results mentioned above, the ginger essential oil dietary level of $0.5 \%$ appears to have had positive immunomodulatory effects on the fish. However, the inclusion of these substances may not positively affect the outcome of the integrated immune response, which in our study would be the survival after the bacterial challenge, in which no significant differences were found between treatments. It could be related to a series of factors, such as dosing, feeding regime, and supplementation times (Pohlenz \& Gatlin III 2014).

\section{CONCLUSION}

Our results indicate that the dietary supplementation of Zingiber officinale essential oil at the supplementation level of $0.5 \%$ had a positive immunomodulatory effect on Pseudoplatystoma reticulatum juveniles, judging from the significantly higher counts of thrombocytes and total leukocytes. However, that did not result in a statistically significant enhanced survival to infection by Aeromonas hydrophila, which could have been caused by the stress induction before the challenge. Liver histomorphometry indicates that the essential oil in levels employed does not negatively affect $P$. reticulatum hepatocytes because their nuclei were not significantly smaller than fish fed the control diet. Furthermore, a significantly larger hepatocyte area found in fish fed the highest does $(1.5 \%)$ suggests an enhanced nutritional status, a hypothesis that could be evaluated in a further study.

\section{ACKNOWLEDGMENTS}

The authors thank the National Council of Scientific and Technological Development (CNPq) for the grant to M.L. Martins (CNPq 306635/2018-6), Coordination for the Improvement of Higher Education Personnel (CAPES) for a Master's scholarship to the first author, and Dr. Francisco C.M. Chaves (Embrapa Western Amazon, AM, Brazil) for oil extraction. Piraí Piscicultura is also acknowledged for donating the fish.

\section{REFERENCES}

Anderson, D.P. \& Siwicki, A.K. 1995. Basic haematology and serology for fish health programs. In: Shariff, M., Arthur, J.R. \& Subasinghe, R.P. (Eds.). Diseases in Asian aquaculture II. Asian Fisheries Society, Manila, pp. 185-202.

Bakkali, F., Averbeck, S., Averbeck, D. \& Idaomar, M. 2008. Biological effects of essential oils - a review. Food and Chemical Toxicology, 46: 446-475. doi: 10.1016/j.fct.2007.09.106

Biller-Takahashi, J.D. \& Urbinati, E.C. 2014. Fish immunology. The modification and manipulation of the innate immune system: Brazilian studies. Annals of the Brazilian Academy of Sciences, 86: 1483-1495. doi: 10.1590/0001-3765201420130159

Brum, A., Cardoso, L., Chagas, E.C., Chaves, F.C.M., Mouriño, J.L.P. \& Martins, M.L. 2018a. Histological changes in Nile tilapia fed essential oils of clove basil and ginger after challenge with Streptococcus agalactiae. Aquaculture, 490: 98-107. doi: 10.1016/j. aquaculture.2018.02.040

Brum, A., Pereira, S.A., Cardoso, L., Chagas, E.C., Chaves, F.C.M., Mouriño, J.L.P. \& Martins, M.L. 2018b. Blood biochemical parameters and melanomacrophage centers in Nile tilapia fed essential oils of clove basil and ginger. Fish and Shellfish Immunology, 74: 444-449. doi: 10.1016/j.fsi.2018.01.021

Brum, A., Pereira, S.A., Owatari, M.S., Chagas, E.C., Chaves, F.C.M., Mouriño, J.L.P. \& Martins, M.L. 2017. Effect of dietary essential oils of clove basil and ginger on Nile tilapia (Oreochromis niloticus) following challenge with Streptococcus agalactiae. Aquaculture, 468: 235-243. doi: 10.1016/j.aquaculture.2016.10.020

Bulfon, C., Volpatti, D. \& Galeotti, M. 2015. Current research on the use of plant-derived products in farmed fish. Aquaculture Research, 46: 513-551. doi: 10.1111/are. 12238

Campos, J.L. 2013. O cultivo do pintado (Pseudoplatystoma corruscans Spix \& Agassiz, 1829) e outras espécies do gênero Pseudoplatystoma e seus híbridos. In: Baldisserotto, B. \& Gomes, L.C. (Eds.). Espécies nativas para a piscicultura no Brasil. Editora da UFSM, Santa Maria, pp. 335-361.

Campos, C.M., Martins, M.A., Martins, M.L., Silva, L.A., Rodrigues, R.A., Pilarski, F. \& Urbinati, E.C. 2020. 
$\beta$-glucan improved growth performance of the catfish Pseudoplatystoma reticulatum without affecting haematological biomarkers after bacterial challenge with Aeromonas hydrophila: a preliminary study. Aquaculture Research, 52: 1311-1315. doi: 10.1111/ are. 14950

Carson, F.L. \& Hladik, C. 2009. Histotechnology: a selfinstructional text. ASCP Press, Chicago.

Collier, H.B. 1944. Standardization of blood haemoglobin determinations. Canadian Medical Association Journal, 50: 550-552.

Crepaldi, D.V., Faria, P.M.C., Teixeira, E.A., Ribeiro, L.P., Costa, A.A.P., Melo, D.C., et al. 2006. O surubim na aquacultura do Brasil. Revista Brasileira de Reprodução Animal, 30: 150-158.

Dairiki, J.K., Majolo, C., Chagas, E.C., Chaves, F.C.M., Oliveira, M.R. \& Morais, I.S. 2013. Procedimento para inclusão de óleos essenciais em rações para peixes. Circular Técnica 42. Embrapa Amazônia Ocidental, Itacoatiara.

Defoirdt, T., Sorgeloos, P. \& Bossier, P. 2011. Alternatives to antibiotics for the control of bacterial disease in aquaculture. Current Opinion in Microbiology, 14: 251-258. doi: 10.1016/j.mib.2011.03.004

Fagundes, M. \& Urbinati, E.C. 2008. Stress in pintado (Pseudoplatystoma corruscans) during farming procedures. Aquaculture, 276: 112-119. doi: 10.1016/ j.aquaculture.2008.02.006

Fazio, F. 2019. Fish hematology analysis as an important tool of aquaculture: a review. Aquaculture, 500: 237242. doi: 10.1016/j.aquaculture.2018.10.030

Ferreira, P.M., Caldas, D.W., Salaro, A.L., Sartori, S.S., Oliveira, J.M., Cardoso, A.J. \& Zuanon, J.A. 2016. Intestinal and liver morphometry of the yellowtail tetra (Astyanax altiparanae) fed with oregano oil. Annals of the Brazilian Academy of Sciences, 88: 911-922. doi: 10.1590/0001-3765201620150202

Ferri-Lagneau, K.F., Moshal, K.S., Grimes, M., Zahora, B., Lv, L., Sang, S. \& Leung, T.C. 2012. Ginger stimulates hematopoiesis via bmp pathway in zebrafish. Plos One, 7: e39327. doi: 10.1371/journal. pone. 0039327

Fox, J. \& Weisberg, S. 2019. An R companion to applied regression. [https://cran.r-project.org/web/packages/ car/index.html]. Reviewed: April 12, 2020.

Goldenfarb, P.B., Bowyer, F.P., Hall, E. \& Brosious, E. 1971. Reproducibility in the hematology laboratory: the microhematocrit determination. American Journal of Clinical Pathology, 56: 35-39. doi: 10.1093/ajcp/ 56.1 .35

Harikrishnan, R., Balasundaram, C. \& Heo, M.S. 2011. Impact of plant products on innate and adaptive immune system of cultured finfish and shellfish. Aquaculture, 317: 1-15. doi: 10.1016/j.aquaculture. 2011.03.039

Hrubec, T.C. \& Smith, S.A. 2010. Hematology of fishes. In: Weiss, D.J. \& Wardrop, K.J. (Eds.). Schalm's veterinary hematology. Wiley-Blackwell, Ames, pp. 994-1003.

Jeena, K., Liju, V.B. \& Kuttan, R. 2013. Antioxidant, antiinflammatory and antinociceptive activities of essential oil from ginger. Indian Journal of Physiology and Pharmacology, 57: 51-62.

Jerônimo, G.T., Brum, A., Pádua, S.B., Gonçalves, E.L.T., Capecci, R.S., Ishikawa, M.M. \& Martins, M.L. 2015. Haematological parameters of the hybrid surubim (Pseudoplatystoma reticulatum $\times P$. corruscans) farmed in Brazil. Brazilian Archives of Biology and Technology, 58: 254-261. doi: 10.1590/S15168913201400180

Kanani, H.G., Nobahar, Z., Kakoolaki, S. \& Jafarian, H. 2014. Effect of ginger- and garlic-supplemented diet on growth performance, some hematological parameters and immune responses in juvenile Huso huso. Fish Physiology and Biochemistry, 40: 481-490. doi: 10.1007/s10695-013-9859-6

Karagouni, E., Athanassopoulou, F., Lytra, A., Komis, C. \& Dotsika, E. 2005. Antiparasitic and immunomodulatory effect of innovative treatments against Myxobolus sp. infection in Diplodus puntazzo. Veterinary Parasitology, 134: 215-228. doi: 10.1016/ j.vetpar.2005.07.020

Lenth, R.V. 2016. Least-squares means: the R package lsmeans. Journal of Statistical Software, 69: 1-33. doi: 10.18637/jss.v069.i01

Mohammadi, G., Rashidian, G., Hoseinifar, S.H., Naserabad, S.S. \& Doan, H.V. 2020. Ginger (Zingiber officinale) extract affects growth performance, body composition, haematology, serum, and mucosal immune parameters in common carp (Cyprinus carpio). Fish and Shellfish Immunology, 99: 267-273. doi: $10.1016 /$ j.fsi.2020.01.032

Mouriño, J.L.P., Pereira, G.V., Vieira, F.N., Jatobá, A.B., Ushizima, T.T., Silva, B.C., et al. 2016. Isolation of probiotic bacteria from the hybrid South American catfish Pseudoplatystoma reticulatum $\times$ Pseudoplatystoma corruscans (Siluriformes: Pimelodidae): a haematological approach. Aquaculture Reports, 3: 166-171. doi: 10.1016/j.aqrep.2016.03.001

Oliveira, R.H.F.D., Silva, E.M.P.D., Bueno, R.S. \& Barone, A.A.C. 2010. The passion fruit on hepatocytes morphometry of Nile tilapia. Ciência Rural, 40: 2562-2567. doi: 10.1590/S0103-84782010001200020 
Picoli, F., Lopes, D.L., Zampar, A., Serafini, S., Freccia, A., Veronezi, L.O., et al. 2019. Dietary bee pollen affects hepatic-intestinal histomorphometry of Nile tilapia fingerlings. Aquaculture Research, 50: 32953304. doi: 10.1111/are.14287

Pohlenz, C. \& Gatlin III, D.M. 2014. Interrelationships between fish nutrition and health. Aquaculture, 431: 111-117. doi: 10.1016/j.aquaculture.2014.02.008

Potzernheim, M.C., Bizzo, H.R., Silva, J.P. \& Vieira, R.F. 2012. Chemical characterization of essential oil constituents of four populations of Piper aduncum L. from Distrito Federal, Brazil. Biochemical Systematics and Ecology, 42: 25-31. doi: 10.1016/j.bse. 2011.12.025

R Core Team. 2019. R: a language and environment for statistical computing. R Foundation for Statistical Computing. [https://www.R-project.org]. Reviewed: March 15, 2020.

Ranzani-Paiva, M.J.T., Pádua, S.B., Tavares-Dias, M. \& Egami, M.I. 2013. Métodos para análise hematológica em peixes. Editora Eduem, Maringá.

Rašković, B.S., Stanković, M.B., Marković, Z.Z. \& Poleksić, V.D. 2011. Histological methods in the assessment of different feed effects on liver and intestine of fish. Journal of Agricultural Sciences (Belgrade), 56: 87-100. doi: 10.2298/JAS1101087R

Rašković, B., Cruzeiro, C., Poleksić, V. \& Rocha, E. 2019. Estimating volumes from common carp hepatocytes using design-based stereology and examining correlations with profile areas: revisiting a nutritional assay and unveiling guidelines to microscopists. Microscopy Research and Technique, 82: 861-871. doi: 10.1002/jemt.23228

Rodrigues, E. 2006. Plants and animals utilized as medicines in the Jaú National Park (JNP), Brazilian Amazon. Phytotherapy Research, 20: 378-391. doi: 10.1002/ptr.1866

Rodrigues, R.A., Saturnino, K.C. \& Fernandes, C.E. 2017. Liver histology and histomorphometry in hybrid sorubim (Pseudoplatystoma reticulatum $\times$ Pseudoplatystoma corruscans) reared on intensive fish farming. Aquaculture Research, 48: 5083-5093. doi: 10.1111/are. 13325

Ross, L.G. \& Ross, B. 2008. Anaesthetic and sedative techniques for aquatic animals. Blackwell Science, Oxford.

Sahoo, P.K., Kumari, J. \& Mishra, B.K. 2005. Nonspecific immune responses in juveniles of Indian major carps. Journal of Applied Ichthyology, 21: 151155. doi: 10.1111/j.1439-0426.2004.00606.x

Sanchez, M.S.S., Rodrigues, R.A., Nunes, A.L., Oliveira, A.M.S., Fantini, L.E. \& Campos, C.M. 2014. Physiological responses of cacharas Pseudoplatystoma reticulatum submitted to natural anesthetics.
Semina: Ciências Agrárias, 35: 1061-1070. doi: 10.5433/1679-0359.2014v35n2p1061

Shehata, S.A., Mohamed, M.S. \& El-Shafi, A. 2013. Antibacterial activity of essential oils and their effects on Nile tilapia fingerlings performance. Journal of Medical Sciences, 13: 367-372. doi: 10.3923/jms. 2013.367.372

Shotts, E.B. \& Rimler, R. 1973. Medium for the isolation of Aeromonas hydrophila. Applied Microbiology, 26: 550-553.

Silva, L.A., Martins, M.A., Santo, F.E., Oliveira, F.C., Chaves, F.C.M., Chagas, E.C., et al. 2020. Essential oils of Ocimum gratissimum and Zingiber officinale as anesthetics for the South American catfish Pseudoplatystoma reticulatum. Aquaculture, 528: 735595. doi: 10.1016/j.aquaculture. 2020.735595

Snuossi, M., Trabelsi, N., Taleb, S.B., Dehmeni, A., Flamini, G. \& De Feo, V. 2016. Laurus nobilis, Zingiber officinale and Anethum graveolens essential oils: composition, antioxidant and antibacterial activities against bacteria isolated from fish and shellfish. Molecules, 21: 1414. doi: 10.3390/molecules 21101414

Sousa, L.C., Moromizato, B.S., Almeida, V.N.S., Miasaki, C.T., Takahashi, L.S. \& Biller, J.D. 2019. There is more than one way of feeding carnivorous fish: surubim (Pseudoplatystoma reticulatum $\times P$. corruscans) are able to cope with carbohydrates rich diets, but there is a trade-off between growth and immunity. Animal Feed Science and Technology, 262: 114382. doi: 10.1016/j.anifeedsci. 2019.114382

Souza, V.L., Lunardi, L.O., Vasques, L.H., Casaletti, L., Nakaghi, L.S.O. \& Urbinati, E.C. 2001. Morphometric alterations in hepatocytes and ultrastructural distribution of liver glycogen in pacu (Piaractus mesopotamicus Holmberg, 1887) during food restriction and refeeding. Journal of Morphological Sciences, 18: 15-20.

Sutili, F.J., Gatlin III, D.M., Heinzmann, B.M. \& Baldisserotto, B. 2018. Plant essential oils as fish diet additives: benefits on fish health and stability in feed. Reviews in Aquaculture, 10: 716-726. doi: 10.1111/ raq. 12197

Tavares-Dias, M. \& Moraes, F.R. 2004. Hematologia de peixes teleósteos. Villimpress, Ribeirão Preto.

Therneau, T. 2020. A package for survival analysis in $\mathrm{R}$ (version 3.2-3). [https://CRAN.R-project.org/package =survival]. Reviewed: March 10, 2020.

Valladão, G.M.R., Gallani, S.U., Pala, G., Jesus, R.B., Kotzent, S., Costa, J.C., et al. 2017. Practical diets with essential oils of plants activate the complement system and alter the intestinal morphology of Nile 
tilapia. Aquaculture Research, 48: 5640-5649. doi: 10.1111/are. 13386

Wendelaar-Bonga, S.E. 1997. The stress response in fish. Physiological Reviews, 77: 591-625. doi: 10.1152/ physrev.1997.77.3.591

Zakęś, Z., Kowalska, A., Demska-Zakęś, K., Jeney, G. \& Jeney, Z. 2008. Effect of two medicinal herbs (Astragalus radix and Lonicera japonica) on the growth performance and body composition of juvenile pikeperch [Sander lucioperca (L.)]. Aquaculture Research, 39: 1149-1160. doi: 10.1111/ j.1365-2109.2008.01977.x

Received: November 9, 2020; Accepted: April 5, 2021
Zar, J.H. 2010. Biostatistical analysis. Prentice-Hall, New Jersey.

Zheng, Z.I., Tan, J.Y.W., Liu, H.Y., Zhou, X.H., Xiang, X. \& Wang, K.Y. 2009. Evaluation of oregano essential oil (Origanum heracleoticum L.) on growth, antioxidant effect and resistance against Aeromonas hydrophila in channel catfish (Ictalurus punctatus). Aquaculture, 292: 214-218. doi: 10.1016/j.aquaculture.2009.04.025 